\title{
Cost Comparison For The Transfer Of Select Calcined Waste Canisters To The Monitored Geologic Repository At Yucca Mountain, Nevada
}

Michael B. Heiser

Clark B. Millet

October 2005 
ICP/EXT-05-00824

Revision 1

Project No. 23582

\title{
Cost Comparison for the Transfer of Select Calcined Waste Canisters to the Monitored Geologic Repository at Yucca Mountain, Nevada
}

\author{
Michael B. Heiser \\ Clark B. Millet
}

October 2005

\section{Idaho Completion Project \\ Idaho Falls, Idaho 83415}

Prepared for the

U.S. Department of Energy

Assistant Secretary for Environmental Management

Under DOE Idaho Operations Office

Contract DE-AC07-99ID13727 


\begin{abstract}
This report performs a life-cycle cost comparison of three proposed canister designs for the shipment and disposition of Idaho National Laboratory high-level calcined waste currently in storage at the Idaho Nuclear Technology and Engineering Center to the proposed national monitored geologic repository at Yucca Mountain, Nevada.

Concept A $(2 \times 10-\mathrm{ft})$ and Concept B $(2 \times 15-\mathrm{ft})$ canisters are comparable in design, but they differ in size and waste loading options and vary proportionally in weight. The Concept $\mathrm{C}(5.5 \times 17.5-\mathrm{ft})$ canister (also called the "super canister"), while similar in design to the other canisters, is considerably larger and heavier than Concept $\mathrm{A}$ and $\mathrm{B}$ canisters and has a greater wall thickness.

This report includes estimating the unique life-cycle costs for the three canister designs. Unique life-cycle costs include elements such as canister purchase and filling at the Idaho Nuclear Technology and Engineering Center, cask preparation and roundtrip consignment costs, final disposition in the monitored geologic repository (including canister off-loading and placement in the final waste disposal package for disposition), and cask purchase.

Packaging of the calcine "as-is" would save $\$ 2.9$ to $\$ 3.9$ billion over direct vitrification disposal in the proposed national monitored geologic repository at Yucca Mountain, Nevada. Using the larger Concept $C$ canisters would use $0.75 \mathrm{mi}$ less of tunnel space, cost $\$ 1.3$ billion less than $10-\mathrm{ft}$ canisters of Concept A, and would be complete in 6.2 years.
\end{abstract}




\section{CONTENTS}

ABSTRACT

iii

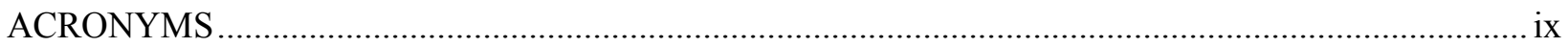

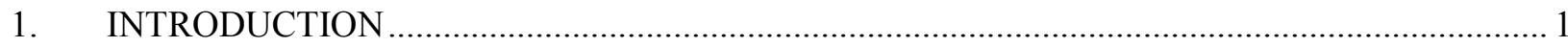

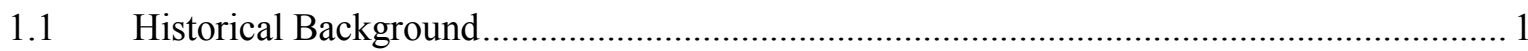

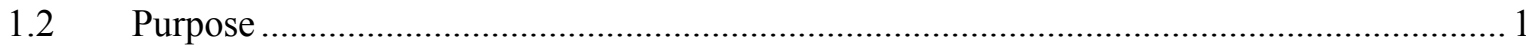

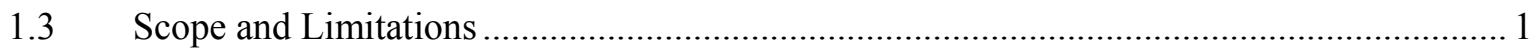

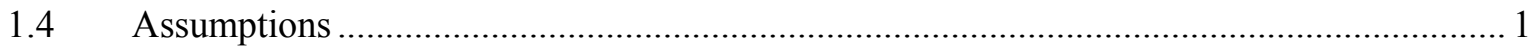

2. CANISTER DESIGN CONCEPTS USED IN THE ANALYSIS ............................................ 3

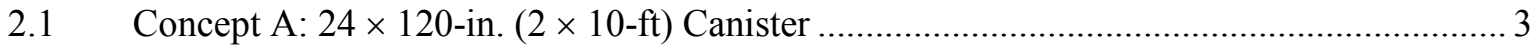

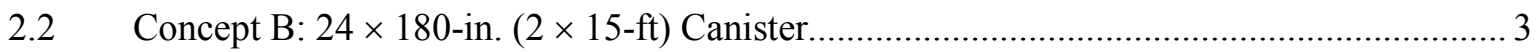

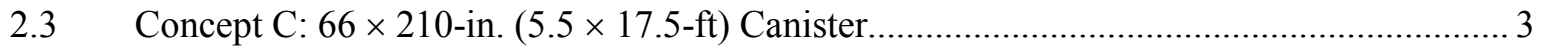

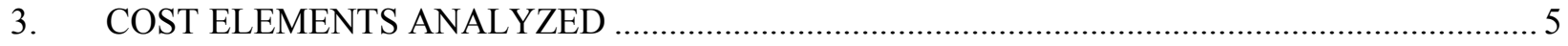

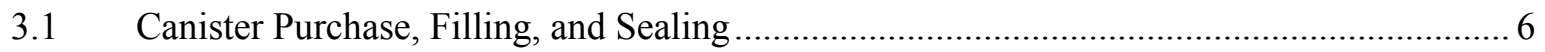

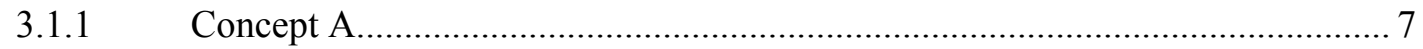

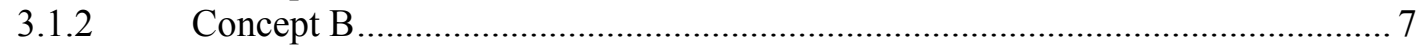

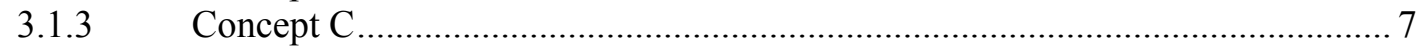

3.2 Shipping-Cask Preparation and Consignment Costs ............................................... 8

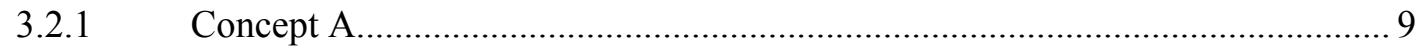

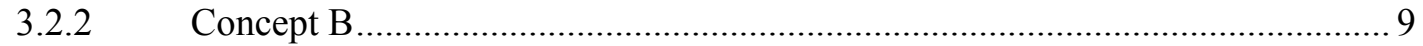

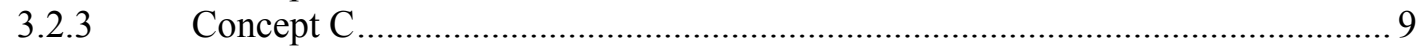

3.3 Canister Handling and Final Disposition at Yucca Mountain .......................................... 10

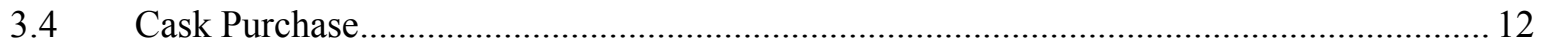

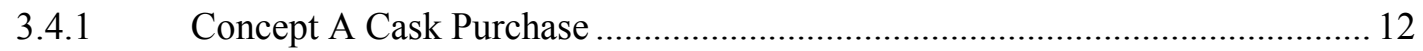

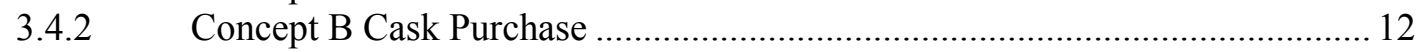

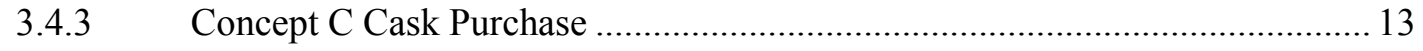

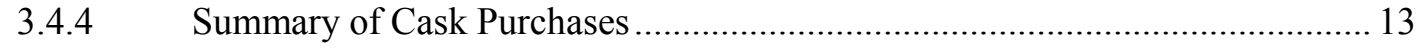




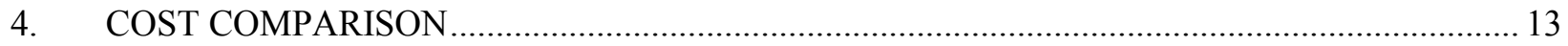

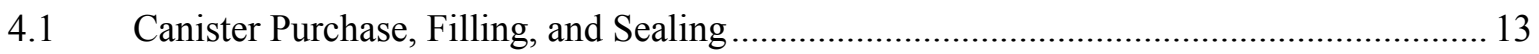

4.2 Shipping-Cask Preparation and Consignment Costs ................................................... 14

4.3 Canister Handling and Final Disposition at the Monitored Geologic Repository ............... 14

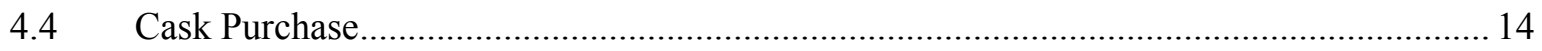

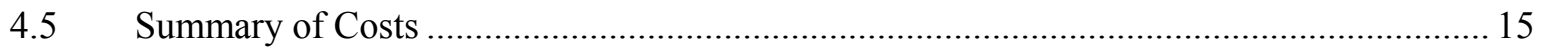

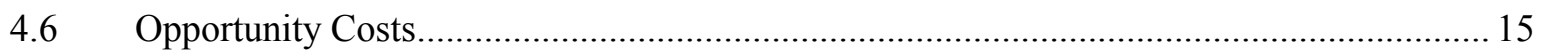

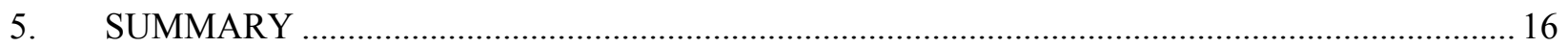

5.1 Comparison of Direct Packaging to Direct Vitrification................................................. 16

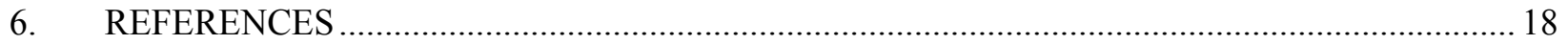

\section{FIGURES}

1. Section view of the 24-in. spent nuclear fuel canister design (EDF-4096, Figure 1, p. 9) ................ 4

2. High-level waste Canister Design Concept B (24 in. diameter $\times 180$ in. long)

(EDF-4096, Figure 3, p. 11).

3. The Idaho National Laboratory's "share" of monitored geologic repository costs

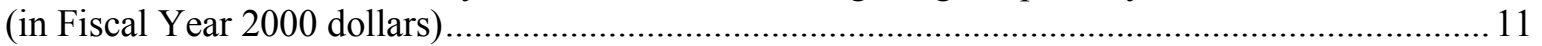

4. Linear feet of tunnel space required (without spacing) for three canister designs ......................... 16

5. Linear feet of Yucca Mountain tunnel space required (without spacing) for three canister designs compared to direct vitrification in 10 -ft canisters

\section{TABLES}

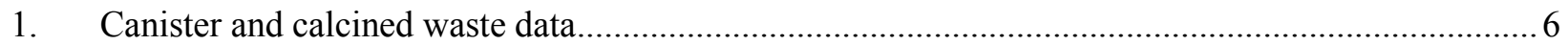

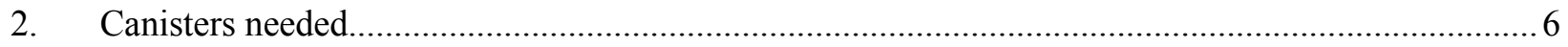

3. Canister purchase, filling, and sealing costs for 6,655 Concept A canisters ................................. 7

4. Canister purchase, filling, and sealing costs for 4,071 Concept B canisters ................................. 7

5. Canister purchase, filling, and sealing costs for 534 Concept $\mathrm{C}$ canisters ..................................... 7 


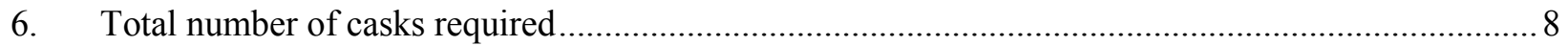

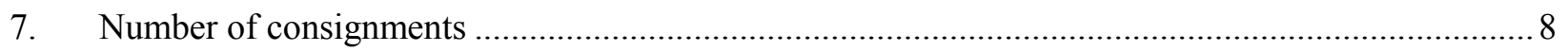

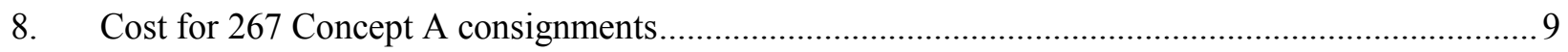

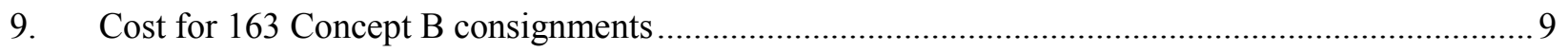

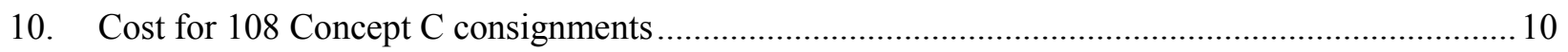

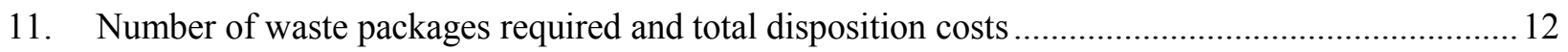

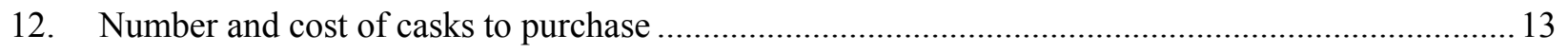

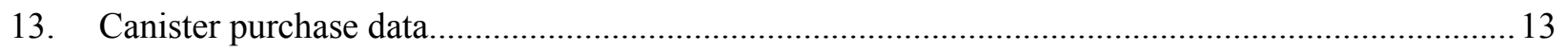

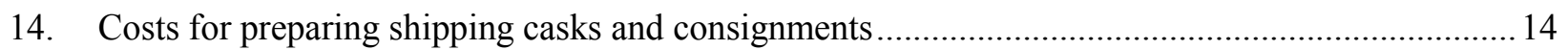

15. Costs for waste package preparation and final disposition at the monitored geologic repository .... 14

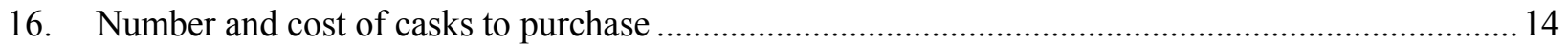

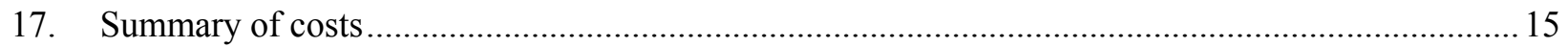

18. Comparison of direct vitrification vs. direct-packaged costs for final disposition at the monitored geologic repository . 


\section{ACRONYMS}

CFR Code of Federal Regulations

DOE U.S. Department of Energy

EDF engineering design file

FY fiscal year

HLW high-level waste

INL Idaho National Laboratory

INTEC Idaho Nuclear Technology and Engineering Center

MGR monitored geologic repository

OCRWM Office of Civilian Radioactive Waste Management (DOE)

SNF spent nuclear fuel

WVSNFS West Valley Spent Nuclear Fuel Shipment 


\section{Cost Comparison for the Transfer of Select Calcined Waste Canisters to the Monitored Geologic Repository at Yucca Mountain, Nevada}

\section{INTRODUCTION}

\subsection{Historical Background}

The Idaho National Laboratory (INL) has been the storage site for calcined high-level nuclear waste solids since the calciner began operations (Stacy 2000, pp. 169-72) at the Idaho Chemical Processing Plant (now called the Idaho Nuclear Technology and Engineering Center [INTEC]). The calciner operated from December 1963 until May 2000 and produced approximately 4,400 $\mathrm{m}^{3}$ $\left(155,800 \mathrm{ft}^{3}\right),{ }^{\mathrm{a}}$ as stored, of solid calcined waste (Staiger and Swenson 2005, Table 1).

Solid calcined waste was produced by processing the high-level liquid waste resulting from the reprocessing of spent nuclear fuels (SNFs). The resulting solids are approximately a seven-fold reduction in volume from the liquid waste (EDF-3673, p. 1) and are in a chemically stable, relatively free-flowing particulate solid form. Calcined waste is stored in six Calcined Solids Storage Facilities at INTEC.

\subsection{Purpose}

The purpose of this report is to identify, quantify, and compare life-cycle costs that are unique to select canister designs for the shipment and disposition of high-level calcined waste from the INTEC to the proposed national monitored geologic repository (MGR) at Yucca Mountain, Nevada.

\subsection{Scope and Limitations}

The scope of this report includes estimating the unique life-cycle costs for three proposed canister designs. Unique life-cycle costs include elements such as canister purchase and filling at INTEC, cask preparation and roundtrip consignment costs, final disposition in the MGR (including canister off-loading and placement in the final waste disposal package for disposition), and cask purchase, which will be the responsibility of the Office of Civilian Radioactive Waste Management (OCRWM). The scope does not include estimating costs for retrieval (assumed to be no difference for the various canister types) or treatment ("as-is" packaging without treatment is assumed) of the calcined waste at INTEC.

\subsection{Assumptions}

For comparison of the canister alternatives, several assumptions must be made. These include the following:

\footnotetext{
a. The rounded numbers in Table 1 of the Calcined Waste Storage at the Idaho Nuclear Technology and Engineering Center (Staiger and Swenson 2005) actually add up to $155,600 \mathrm{ft}^{3}$ of calcined waste, but converting 4,411 $\mathrm{m}^{3}$ (also from Table 1 of the aforementioned report [Staiger and Swenson 2005]) — a more precise value — to cubic feet using the conversion factor of $35.315 \mathrm{ft}^{3}$ per cubic meter results in $155,774 \mathrm{ft}^{3}$ rounded up to $155,800 \mathrm{ft}^{3}$. The slightly higher figure was chosen for this analysis to err on the high side.
} 
1. This cost analysis is meant to be differential/comparative rather than absolute; costs are escalated as necessary to be reported in current (2005) dollars. No other escalation or discounting is included to reflect time value of money.

2. Calcined waste will be directly packaged and shipped "as is" and will not be treated.

3. There may be SNF co-shipped with calcined waste canisters in the same shipping cask.

4. While there may be co-disposal of SNF and calcined waste within the same waste disposal package at the MGR, for purposes of this analysis, no cost or credit is assigned (see Section 4.6, "Opportunity Costs").

5. Retrieval costs for the calcined waste are assumed to be approximately the same for each of the canister design concepts; therefore, these costs are not included in this analysis.

6. Capital facilities at the INTEC likely will be equivalent regardless of design concept; therefore, these costs are not included in this analysis.

7. The average bulk density assumed for the calcined waste after emplacement in the canisters is $79.74 \mathrm{lb} / \mathrm{ft}^{3}\left(1.28 \mathrm{~g} / \mathrm{cm}^{3}\right)($ EDF-4504, p. 19).

8. The volume-percent fill capacity of each of the canister designs is as follows: Concept A may be filled to 98\%; Concept B may be filled to $98 \%$ (EDF-4096, p. 16); and Concept C may be filled to 92\% (EDF-4096, p. 16).

9. The canisters will be fabricated from 316L stainless steel (EDF-4096, p. 15).

10. Design and qualification costs for each design concept are approximately the same; therefore, these costs are not included in this analysis.

11. All consignments will be by rail from the INTEC to the MGR with no incidents, handling, transfer, or storage in transit; this assumes a rail system will be built to accommodate shipping to the MGR and that such rail system is a fixed project cost not included in this analysis.

12. Each roundtrip consignment will consist of five shipping casks per consignment.

13. Each roundtrip consignment will take no more than 3 weeks to complete ( 5 days to load at the INTEC, 3-day transit from the INTEC to the MGR, 5 days to unload at the MGR, 3-day transit from the MGR to the INTEC, and 5-day contingency for weather delays).

14. The same size and type of cask will be used for shipping the three canister types. (Spacers within the casks would be needed for Concept A and Concept B canisters, but are considered to be a negligible additional cost.)

15. The shipping campaign will take place over no more than 12 years.

16. There will be minimal storage of empty and/or filled, "road ready" canisters in Idaho.

17. There will be minimal surface storage of filled canisters prior to waste packaging for final disposition in the MGR subsurface facilities.

18. No decontamination and decommissioning costs for handling/storage facilities are included. 
19. Consignments will comply with all applicable laws and regulations (e.g., 10 CFR 71 and the MGR waste acceptance criteria).

20. Values for volumes and weights are approximations; therefore, they are rounded to the nearest whole number for pounds and to the nearest $1 / 10$ for cubic feet.

21. Cost values are rounded to the nearest $\$ 1,000(\$ 1 \mathrm{~K})$.

22. The transportation costs of shipping five casks on a routine basis would be equal to the actual cost experienced of shipping two SNF casks, as discussed in Section 3.2 (Keister 2002).

\section{CANISTER DESIGN CONCEPTS USED IN THE ANALYSIS}

This chapter contains a discussion of the three canister designs selected for this report.

\subsection{Concept A: $24 \times 120$-in. $(2 \times 10-\mathrm{ft})$ Canister}

This design, sometimes referred to as the "SNF canister" (Figure 1), is similar to the Concept B design (see Section 2.2 and Figure 2) except that its overall length is 120 in. rather than $180 \mathrm{in}$. Its outside diameter is $24 \mathrm{in}$. The wall thickness is $0.375 \mathrm{in}$. Its approximate empty weight would be $1,100 \mathrm{lb}$ assuming that it is approximately $2 / 3$ the weight of Concept B and accounting for extra weight of the bottom and head.

\subsection{Concept B: $24 \times 180$-in. $(2 \times 15-\mathrm{ft})$ Canister}

This design is similar to the 24-in.-diameter U.S. Department of Energy (DOE) SNF canister design (EDF-4096, p. 8). The chief differences between the SNF canister (Figure 1) and this canister, sometimes referred to as the "high-level waste (HLW) canister" (Figure 2), are:

- A modified top head to allow loading of calcined waste

- $\quad$ No internal impact plates

- $\quad$ A possible modified bottom head with no plug.

The length of this canister is 180 in., which is $50 \%$ longer than the SNF canister. The wall thickness is $0.375 \mathrm{in}$., which is a variation of the original HLW canister concept that used a thickness of 0.5 in. This was determined to have no "dire consequences" in its overall performance (EDF-4096, p. 106). Its approximate empty weight would be 1,550 lb (EDF-4096, Table 35, p. 105).

\subsection{Concept C: $66 \times 210$-in. $(5.5 \times 17.5-f t)$ Canister}

This design is similar to the Concept B design (see Section 2.2) with an outside diameter of 66 in. and an overall length of 210 in. (EDF-4096, p. 11). It is sometimes referred to as the "super canister." Like Concept B, there would be no internal impact plates, and the top head would accommodate loading of calcined waste into the canister. The variation selected for this analysis has a wall thickness of $0.75 \mathrm{in}$. Engineering Design File (EDF) -4096 (p. 106) states that a wall/head thickness of 0.75 in. appears to be the best choice for this design concept. The approximate empty weight of this canister would be 10,970 lb (EDF-4096, Table 35, p. 105). 


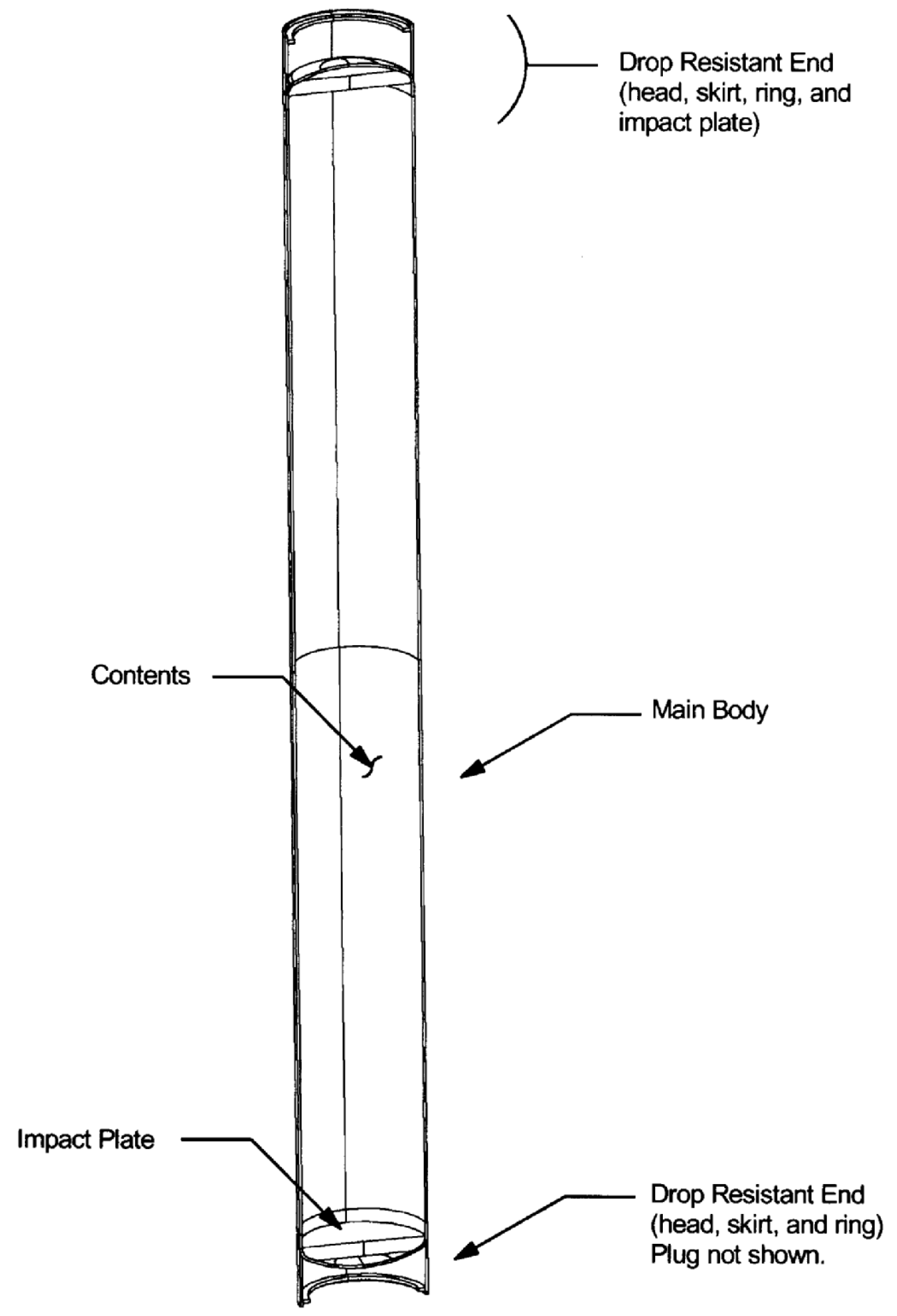

Figure 1. Section view of the 24-in. spent nuclear fuel canister design (EDF-4096, Figure 1, p. 9). 

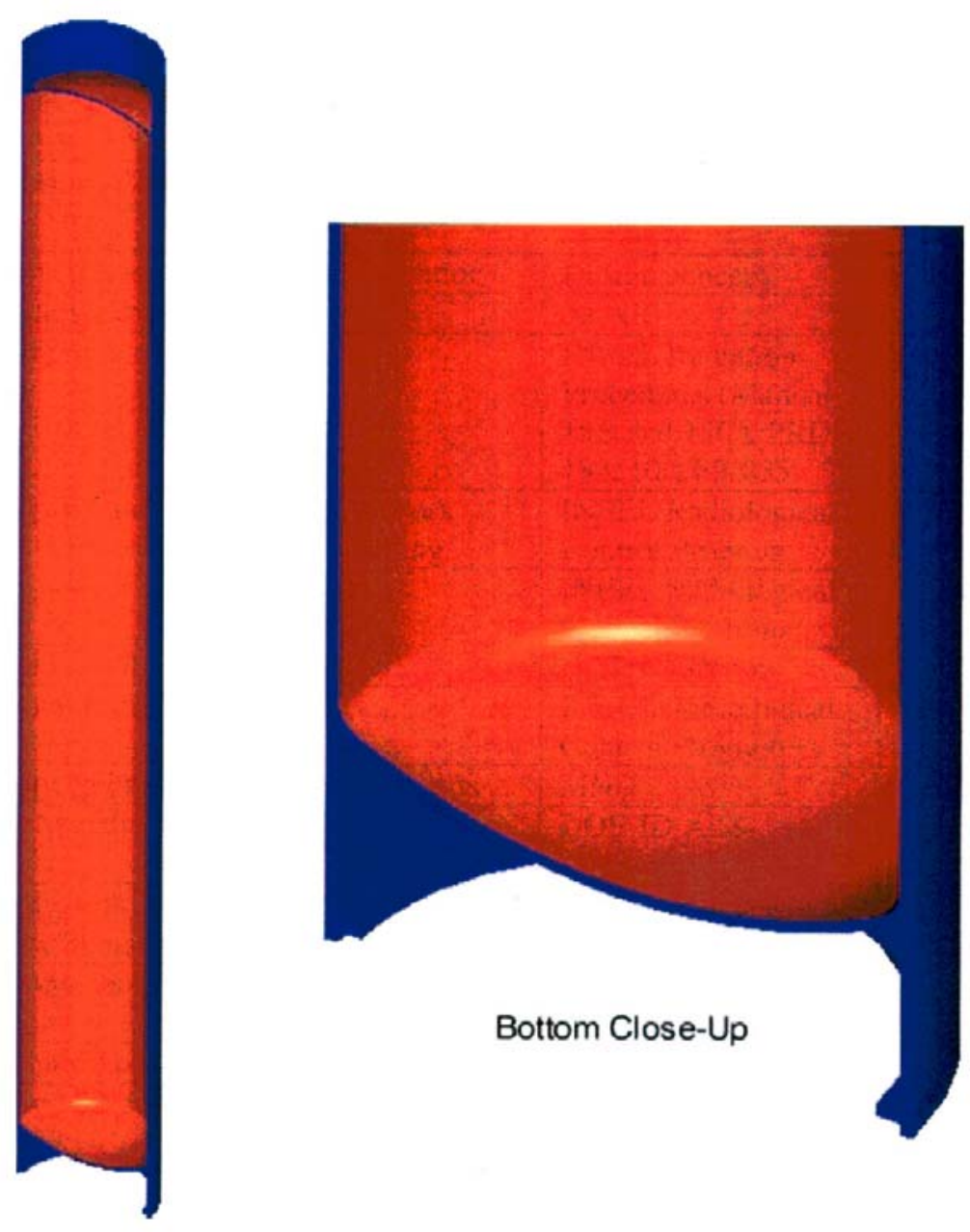

Figure 2. High-level waste Canister Design Concept B (24 in. diameter $\times 180$ in. long) (EDF-4096, Figure 3, p. 11).

\section{COST ELEMENTS ANALYZED}

This section contains a discussion of each of the cost elements in the analysis. Each element is quantified to the extent possible for each canister concept. Cost elements include (1) purchasing the required number of canisters and filling and sealing canisters; (2) preparing the shipping casks and making the required number of roundtrip consignments; (3) final disposition in the MGR, including all purchasing of waste packages and handling, filling, and emplacement operations; and (4) purchasing the required number of casks to complete the consignments in less than 12 years.

Table 1 contains data that are used in the discussion of each cost element. Weight data for Concepts B and C are taken from EDF-4096 (Table 35, p. 105). The weight for Concept A was calculated for this analysis based on datum for Concept $\mathrm{B}$ assuming that the Concept $\mathrm{A}$ canister weight would be approximately $2 / 3$ of the Concept B canister weight. This value $(1,033 \mathrm{lb})$ was then rounded up to $1,100 \mathrm{lb}$ to account for the additional weight of the canister bottom and head. This value has excellent correlation with calculated mass using the dimensions and the density of 304L stainless steel. Volume data for Concepts A and B were calculated using an internal usable height of 97.25 in. and 159 in., respectively, from Preliminary Design Specification for Department of Energy Standardized Spent 
Nuclear Fuel Canisters (DOE 1999, Table 3.1, p. 5). The volume for Concept C canister was obtained using the same internal height as the 66-in. canister in Table 5 of EDF-4096 (Table 5, p. 16). ${ }^{\text {b }}$

Table 1. Canister and calcined waste data.

\begin{tabular}{ccccccc}
\hline $\begin{array}{c}\text { Design } \\
\text { Concept }\end{array}$ & $\begin{array}{c}\text { Empty Canister } \\
\text { Weight } \\
(\mathrm{lb})\end{array}$ & $\begin{array}{c}\text { Calcine } \\
\text { Weight } \\
(\mathrm{lb})\end{array}$ & $\begin{array}{c}\text { Filled Canister } \\
\text { Weight } \\
(\mathrm{lb})\end{array}$ & $\begin{array}{c}\text { Canister } \\
\text { Volume } \\
\left(\mathrm{ft}^{3}\right)\end{array}$ & $\begin{array}{c}\text { Volume } \\
\% \text { Full }\end{array}$ & $\begin{array}{c}\text { Calcine } \\
\text { Volume } \\
\left(\mathrm{ft}^{3}\right)\end{array}$ \\
\hline Concept A & 1,100 & 1,867 & 2,967 & 23.9 & 98 & 23.4 \\
Concept B & 1,550 & 3,053 & 4,603 & 39.1 & 98 & 38.3 \\
Concept C & 10,970 & 23,304 & 34,274 & 317.7 & 92 & 292.3 \\
\hline
\end{tabular}

Given a total volume of $155,800 \mathrm{ft}^{3}$ calcined waste, the number of canisters needed for each design concept is shown in Table 2. The total number of canisters is calculated by dividing the volume of calcined waste $\left(155,800 \mathrm{ft}^{3}\right)$ by the calcined waste volume capacity per canister and rounding up to the next whole number, since normal rounding would underestimate the number of canisters in some cases.

Table 2. Canisters needed.

\begin{tabular}{lcccc}
\hline Design Concept & $\begin{array}{c}\text { Canister } \\
\text { Volume } \\
\left(\mathrm{ft}^{3}\right)\end{array}$ & $\begin{array}{c}\text { Volume \% } \\
\text { Full }\end{array}$ & $\begin{array}{c}\text { Calcine } \\
\text { Volume } \\
\left(\mathrm{ft}^{3}\right)\end{array}$ & $\begin{array}{c}\text { Number of } \\
\text { Canisters } \\
\text { Needed }\end{array}$ \\
\hline Concept A & 23.9 & 98 & 23.4 & 6,655 \\
Concept B & 39.1 & 98 & 38.3 & 4,071 \\
Concept C & 317.7 & 92 & 292.3 & 534 \\
\hline
\end{tabular}

\subsection{Canister Purchase, Filling, and Sealing}

This cost element includes the cost to purchase the required number of canisters, fill them with calcined waste, and seal them for shipping. The INTEC personnel costs for receiving, moving, and filling operations would include equipment operators, rigging/hoisting operators, safety, radiation control, and quality assurance. Equipment costs would include use of forklifts, shielding, filling equipment, cranes, etc. The costs to retrieve the calcined waste are considered to be about the same for all canister design concepts; therefore, these costs are not included in this analysis (see Assumption \#5 in Section 1.4). The number of hours required for each design concept to remove empty canisters from storage, fill them, seal them, and return the filled canisters to storage will vary. It is assumed that there will be minimal storage of filled "road ready" canisters in Idaho (see Assumption \#16 in Section 1.4).

The purchase estimates are based on a memorandum entitled "DOE Standardized Spent Nuclear Fuel Canisters" (Bradford and Wheatley 1998), which is a detailed cost estimate that was completed in 1998 for the standard 18-in. $\times 15$-ft SNF canister. Those costs are escalated by $3 \%$ per year to 2005 . It is assumed that the materials and labor needed for the SNF canister would be about equal to the material and labor needed to produce the 24-in. HLW Concept B canister. The empty weights of the two canisters are similar: 1,200 and 1,550 lb, respectively. Those dollar figures are then calculated on a per-pound basis for

b. The volume value in EDF-4096, Table 5 of 526,530 in. ${ }^{3}$ was used to calculate a height given the internal diameter of 63.25 in. (66 in. minus 2 times the wall thickness of 1.375 in.). 
the empty SNF canister (approximately $\$ 27$ per pound) and used to calculate costs for Concept A, Concept $\mathrm{B}$, and Concept $\mathrm{C}$ canisters based on their empty weights.

\subsubsection{Concept A}

To transport the required amount of calcined waste, 6,655 Concept A canisters would be necessary. Each canister costs $\$ 29.7 \mathrm{~K}$. It is estimated that a five-person crew (equipment operations, rigging, safety, quality control, and radiation control) working 10 hours at an average of $\$ 100$ per hour for each canister for receiving, moving, filling, and sealing is required. These personnel and equipment costs would therefore be about $\$ 5 \mathrm{~K}$ per canister. These costs are summarized in Table 3.

Table 3. Canister purchase, filling, and sealing costs for 6,655 Concept A canisters.

\begin{tabular}{|c|c|c|}
\hline Element & Cost per Canister $(\$ K)$ & Total $(\$ K)$ \\
\hline Canister Purchase & $\$ 29.7$ & $\$ 197,654$ \\
\hline Personnel and Equipment Costs & $\$ 5.0$ & $\$ 33,275$ \\
\hline Total & $\$ 34.7$ & $\$ 230,927$ \\
\hline
\end{tabular}

\subsubsection{Concept B}

To transport the required amount of calcined waste, 4,071 Concept B canisters would be necessary. Each canister costs $\$ 41.9 \mathrm{~K}$. It is estimated that a five-person crew (equipment operations, rigging, safety, quality control, and radiation control) working 12 hours at an average of $\$ 100$ per hour for each canister for receiving, moving, filling, and sealing is required. These personnel and equipment costs would therefore be about $\$ 6.0 \mathrm{~K}$ per canister. These costs are summarized in Table 4.

Table 4. Canister purchase, filling, and sealing costs for 4,071 Concept B canisters.

\begin{tabular}{|c|c|c|}
\hline Element & Cost per Canister $(\$ K)$ & Total $(\$ K)$ \\
\hline Canister Purchase & $\$ 41.9$ & $\$ 170,371$ \\
\hline Personnel and Equipment Costs & $\$ 6.0$ & $\$ 24,426$ \\
\hline $\begin{array}{r}\text { Total } \\
\end{array}$ & $\$ 47.9$ & $\$ 194,797$ \\
\hline
\end{tabular}

\subsubsection{Concept C}

To transport the required amount of calcined waste, 534 Concept $\mathrm{C}$ canisters would be necessary. Each canister costs $\$ 296.2 \mathrm{~K}$. It is estimated that a five-person crew (equipment operations, rigging, safety, quality control, and radiation control) working 20 hours at an average of $\$ 100$ per hour for each canister for receiving, moving, filling, and sealing is required. These personnel and equipment costs therefore would be about $\$ 10 \mathrm{~K}$ per canister. These costs are summarized in Table 5.

Table 5. Canister purchase, filling, and sealing costs for 534 Concept $\mathrm{C}$ canisters.

\begin{tabular}{|c|c|c|}
\hline Element & Cost per Canister $(\$ K)$ & Total $(\$ K)$ \\
\hline Canister Purchase & $\$ 296.2$ & $\$ 158,165$ \\
\hline Personnel and Equipment Costs & $\$ 10.0$ & $\$ 5,340$ \\
\hline Total & $\$ 306.2$ & $\$ 163,505$ \\
\hline
\end{tabular}




\subsection{Shipping-Cask Preparation and Consignment Costs}

Tasks in this element include preparation and roundtrip consignment costs. This includes subtasks at INTEC of receiving the rail cars and opening the shipping casks, removing filled canisters from storage, placing filled canisters in the shipping casks, closing the shipping casks, and preparing surveys and shipping papers.

Table 6 summarizes the number of casks needed for each design concept if the canisters were packaged in casks all at once. The total number of casks is calculated by dividing the number of canisters by the number of canisters per cask and rounding up to the next whole number, since normal rounding would underestimate the number of casks in some cases. Note that this number represents the total number of casks if they were filled all at once and not the actual number of casks that would need to be purchased, which is dependent on number of casks per consignment, scheduling, length of shipping campaign, and other factors to be discussed in Section 3.4.

Table 6. Total number of casks required.

\begin{tabular}{lccc}
\hline Design Concept & $\begin{array}{c}\text { Number } \\
\text { of Canisters }\end{array}$ & $\begin{array}{c}\text { Number of } \\
\text { Canisters per Cask }\end{array}$ & $\begin{array}{c}\text { Number } \\
\text { of Casks }\end{array}$ \\
\hline Concept A & 6,655 & 5 & 1,331 \\
Concept B & 4,071 & 5 & 815 \\
Concept C & 534 & 1 & 534 \\
\hline
\end{tabular}

The major cost in this element consists of the actual shipment by rail of the prepared shipping casks from the INTEC to the MGR and their return (empty) to the INTEC. This assumes a rail line from the INTEC to the MGR is available (see Assumption \#11 in Section 1.4). The 2005 shipping cost estimate for each consignment round trip of $\$ 240 \mathrm{~K} /$ consignment is based on a 2003 cost of $\$ 226 \mathrm{~K} /$ consignment escalated at 3\% for 2 years. The cost was a Union Pacific Railroad shipping cost (Keister 2002) for two SNF casks by rail for the West Valley Spent Nuclear Fuel Shipment (WVSNFS) from West Valley, New York, to Idaho Falls, Idaho, on July 13-17, 2003. The Union Pacific portion of the route was from Kansas City, Missouri, to the INL in Idaho, which is roughly equivalent in distance (approximately $1,000 \mathrm{mi}$ ) to a round trip from the INTEC to the MGR. It is assumed that rail contracts, security requirements, inspections, train crews, equipment, etc., needed for each round trip would be similar to those required for the WVSNFS.

Table 7 summarizes the number of consignments needed for each design concept. The total number of consignments is calculated by dividing the total number of casks needed by the number of casks per consignment and rounding up to the next whole number since normal rounding would underestimate the number of consignments in some cases.

Table 7. Number of consignments.

\begin{tabular}{lccc}
\hline Design Concept & $\begin{array}{c}\text { Number of } \\
\text { Casks Needed }\end{array}$ & $\begin{array}{c}\text { Number of Casks } \\
\text { per Consignment }\end{array}$ & $\begin{array}{c}\text { Number of } \\
\text { Consignment }\end{array}$ \\
\hline Concept A & 1,331 & 5 & 267 \\
Concept B & 815 & 5 & 163 \\
Concept C & 534 & 5 & 108 \\
\hline
\end{tabular}




\subsubsection{Concept A}

Each roundtrip consignment cost is estimated to be about $\$ 240 \mathrm{~K}$ from the INTEC to the MGR. It is estimated that a five-person crew (equipment operations, rigging, safety, quality control, and radiation control) working 2 hours at an average of $\$ 100$ per hour for each canister to be loaded into a cask is required. Therefore, these personnel and equipment costs would be about $\$ 1 \mathrm{~K}$ per canister or $\$ 5 \mathrm{~K}$ per cask or $\$ 25 \mathrm{~K}$ per consignment of five casks for Concept A canisters. These costs are summarized in Table 8 .

Table 8. Cost for 267 Concept A consignments.

\begin{tabular}{|c|c|c|}
\hline Element & $\begin{array}{c}\text { Cost per Consignment } \\
(\$ \mathrm{~K})\end{array}$ & $\begin{array}{l}\text { Total } \\
(\$ K)\end{array}$ \\
\hline Roundtrip Consignment & $\$ 240.0$ & $\$ 64,080$ \\
\hline Personnel and Equipment & $\$ 25.0$ & $\$ 6,675$ \\
\hline Total & $\$ 265.0$ & $\$ 70,755$ \\
\hline
\end{tabular}

\subsubsection{Concept B}

Each roundtrip consignment cost is estimated to be about $\$ 240 \mathrm{~K}$ from the INTEC to the MGR. It is estimated that a five-person crew (equipment operations, rigging, safety, quality control, and radiation control) working 2 hours at an average of $\$ 100$ per hour for each canister to be loaded into a cask is required. Therefore, these personnel and equipment costs would be about $\$ 1 \mathrm{~K}$ per canister or $\$ 5 \mathrm{~K}$ per cask or $\$ 25 \mathrm{~K}$ per consignment of five casks for Concept B canisters. These costs are summarized in Table 9.

Table 9. Cost for 163 Concept B consignments.

\begin{tabular}{|c|c|c|}
\hline Element & $\begin{array}{c}\text { Cost per Consignment } \\
(\$ K)\end{array}$ & $\begin{array}{l}\text { Total } \\
(\$ K)\end{array}$ \\
\hline Roundtrip Consignment & $\$ 240.0$ & $\$ 39,120$ \\
\hline Personnel and Equipment & $\$ 25.0$ & $\$ 4,075$ \\
\hline Total & $\$ 265.0$ & $\$ 43,195$ \\
\hline
\end{tabular}

\subsubsection{Concept C}

Each roundtrip consignment cost is estimated to be about $\$ 240 \mathrm{~K}$ from the INTEC to the MGR. It is estimated that a five-person crew (equipment operations, rigging, safety, quality control, and radiation control) working 2 hours at an average of $\$ 100$ per hour for each canister to be loaded into a cask is required. Therefore, these personnel and equipment costs would be about $\$ 1 \mathrm{~K}$ per canister or $\$ 1 \mathrm{~K}$ per cask or $\$ 5 \mathrm{~K}$ per consignment of five casks for Concept $\mathrm{C}$ canisters. These costs are summarized in Table 10 . 
Table 10. Cost for 108 Concept $\mathrm{C}$ consignments.

\begin{tabular}{lccc}
\hline & & $\begin{array}{c}\text { Cost per Consignment } \\
\text { Element }\end{array}$ & $\begin{array}{c}\text { Total } \\
(\$ \mathrm{KK})\end{array}$ \\
\hline Roundtrip Consignment & $\$ 240.0$ & $\$ 25,920$ \\
Personnel and Equipment & $\$ 5.0$ & $\$ 540$ \\
\cline { 2 - 3 } & Total & $\$ 245.0$ & $\$ 26,460$ \\
\hline
\end{tabular}

\subsection{Canister Handling and Final Disposition at Yucca Mountain}

This cost element is by far the largest contributor to this analysis. Tasks in this cost element include purchasing the required number of waste packages, receiving the shipping casks at the MGR, removing the canisters from the shipping casks and transferring them directly into waste packages, sealing the waste packages, and performing final disposition of the waste packages in the MGR. Shipping casks would then be prepared for return to the INTEC (preparation and actual shipping costs are included under the roundtrip consignment costs in Section 3.2, "Shipping Cask Preparation and Consignment Costs").

The estimated cost share for DOE materials for disposition in the MGR is $\$ 15.66$ billion in Fiscal Year (FY) 2000 dollars (DOE 2001, Table 7-1, p. 7-2). This cost is inclusive of waste package purchase, all handling operations (e.g., filling and sealing) at MGR surface facilities, and final disposition in the MGR subsurface facility. It is based on a total of 26,288 canisters for disposition, which includes 22,147 DOE HLW canisters (DOE 2001, Table 4-3) and 4,141 DOE SNF canisters (DOE 2001, Table 4-2). These estimates contained 1,292 HLW canisters from the INL. If the cost is figured on a per-canister basis, it would be approximately $\$ 595.7 \mathrm{~K}$ per canister. However, the $\$ 15.66 \mathrm{~B}$ figure is a relatively fixed facility cost only as long as the total canister count (volume of waste disposed) does not change (increase) enough to require building new subsurface disposal areas. In any case, the "share" cannot be expressed on a per-canister basis since by doing so it would grossly underestimate the total cost for disposition of larger canisters. In other words, with fewer canisters, but the same volume of waste, the cost would still be about $\$ 15.66 \mathrm{~B}$ to DOE and the cost per canister would have to increase proportionately. If escalation is applied at 3\% per year to 2005, the MGR cost becomes $\$ 18.15$ billion and the cost per canister $\$ 690.6 \mathrm{~K}$. The INL share would be $\$ 892,242 \mathrm{~K}$. In order to ship a higher number of canisters from Idaho without increasing the total MGR cost, we must assume we can use more allotments than the 1,292 within the 22,147 DOE HLW canister count. Based on this assumption, the cost would remain at $\$ 690.6 \mathrm{~K}$ per canister. For the Concept A shipment case, the INL share would be $\$ 4,595.9 \mathrm{M}$.

The "Total System Life Cycle Cost" analysis contained in the Total System Life Cycle Cost Study of the Civilian Radioactive Waste Management Program (DOE 2001) was based on a minimal volume of waste (canister count) coming from the INL, based on an elaborate chemical separations process, which would feed a small concentrate of very high-activity waste to a vitrification system. This overall treatment process has been judged to be far too complex, technically risky, and costly, and it has been replaced by direct vitrification of calcine as the baseline process scenario for the INL. Direct vitrification would result in approximately nine times more waste volume to be disposed of at the repository (approximately 12,000 versus 1,292 10-ft canisters). With this significant increase, the "Idaho share" of the repository would be expected to increase. (Note that the INL is now proposing direct packaging ["as-is" disposal] of calcine in place of direct vitrification. Direct packaging would result in less waste volume [smaller canister count] than direct vitrification.) 
A study (Lopez 2002) was commissioned to evaluate costs for various treatment scenarios in Idaho that would generate significantly different total waste volumes and canister counts in order to see how Idaho's share of the repository costs varies with waste volume disposed. Figure 3 takes data from Lopez (2002), Table 3-7, p. 17, and graphs it to determine the INL share of the MGR costs as a function of the total number of 10-ft canisters disposed of. The equation developed from this graph gives a fair representation for the disposal of 6,655 Concept A canisters. In FY 2000 dollars, the total cost for the disposal of 6,655 Concept A canisters would be about $\$ 3,780.0 \mathrm{M}$. Escalated at 3\% per year to 2005, this figure would be about $\$ 4,382.1 \mathrm{M}$ (or about $\$ 658.5 \mathrm{~K}$ per Concept A canister). These cost values are within $5 \%$ of $\$ 690.6 \mathrm{~K}$ per canister (DOE 2001) discussed above.

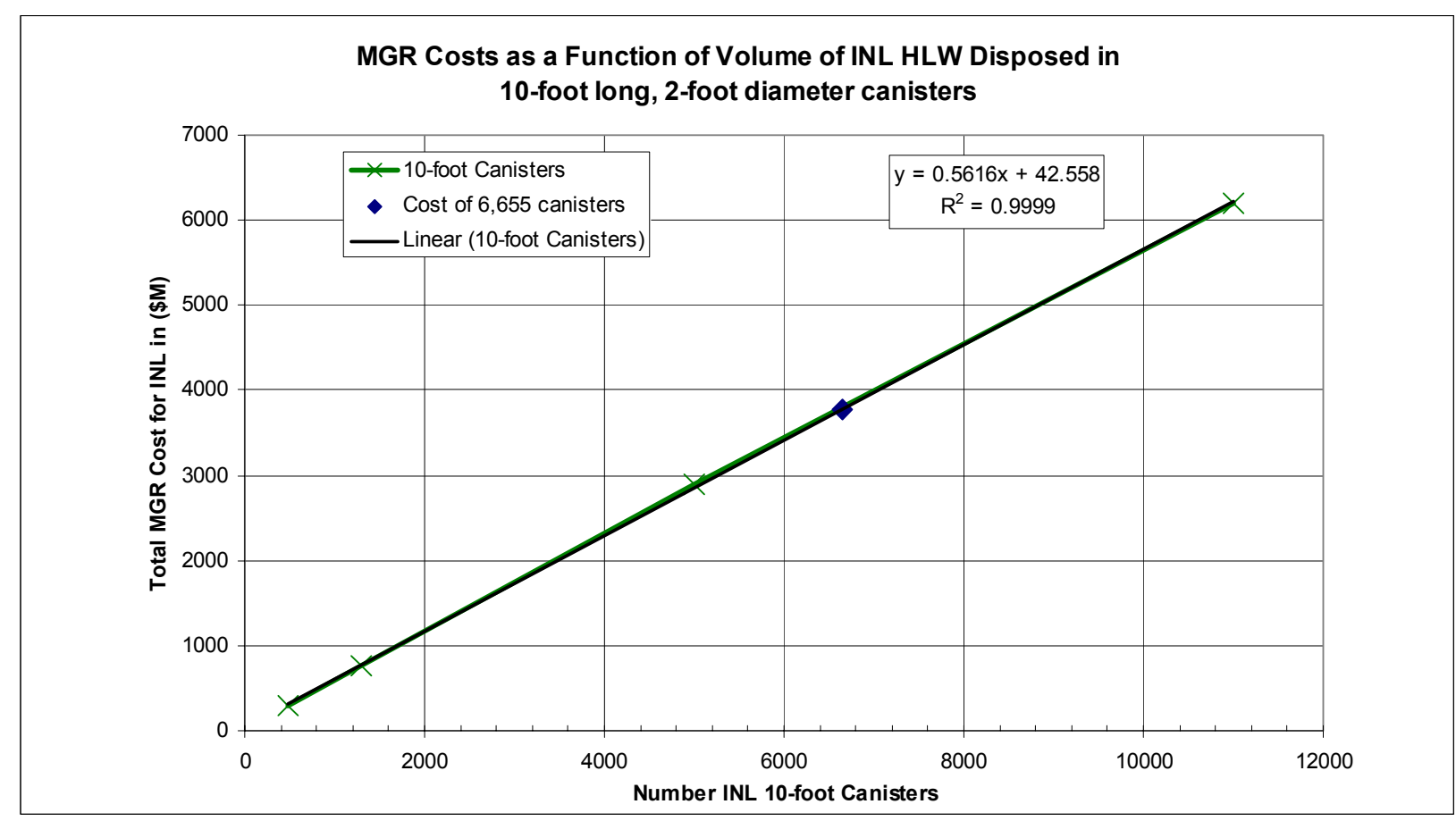

Figure 3. The Idaho National Laboratory's "share" of monitored geologic repository costs (in Fiscal Year 2000 dollars).

However, as noted above, figuring the cost based on just a canister count would still grossly underestimate the costs for some of the larger canisters (particularly Concept C). A fairer assignment of the costs could be made on the linear feet of tunnel required (this is discussed in more detail in Section 4.6, "Opportunity Costs"). Without accounting for additional spacing between fewer waste packages, the space required is $10 \mathrm{ft}$ for Concept A versus $15 \mathrm{ft}$ for Concept $\mathrm{B}$ and $17.5 \mathrm{ft}$ for Concept $\mathrm{C}$. The space required for the disposition of Concept $C$ canisters would result in about 9,345 linear $\mathrm{ft}$. Concept A would require about 13,310 linear $\mathrm{ft}$ and Concept B would require about 12,225 linear ft. This adds up to a savings in linear feet of tunnel space for Concept $C$ of a maximum of 3,965 ft (0.75 mi).

Cost savings can be ratioed proportional to tunnel space requirements for the three canister design concepts. Viewed in this way, the total $\$ 4,595.9 \mathrm{M}$ (Idaho's share) could be assigned to Concept A (at $\$ 690.6 \mathrm{~K}$ per Concept A canister), since it requires the most tunnel space. Concept B requires $8 \%$ less space $(1,085 \mathrm{ft}$ less) than Concept $\mathrm{A}$. Concept $\mathrm{C}$, however, represents a $30 \%$ reduction in required tunnel space. Reducing the total MGR cost share for Idaho proportional to the linear feet of tunnel space would give a fairer cost reduction for each case. The cost per linear foot of tunnel would be $\$ 345.3 \mathrm{~K}$. The total MGR cost share proportionate to the tunnel space requirement for Concept B would give a total figure of 
about $\$ 4,221.2 \mathrm{M}$ (or about $\$ 1,036.9 \mathrm{~K}$ per Concept $\mathrm{B}$ canister). The total MGR cost share proportionate to the tunnel space requirement for Concept $\mathrm{C}$ would give a total figure of about $\$ 3,226.8 \mathrm{M}$ (or about $\$ 6,042.7 \mathrm{~K}$ per Concept $\mathrm{C}$ canister).

Table 11 summarizes the number of waste packages needed for each design concept and their proportional costs for disposition in the MGR. The total number of waste packages needed is calculated by dividing the number of canisters by the number of canisters per waste package and rounding up to the next whole number, since normal rounding would underestimate the number of waste packages in some cases.

Table 11. Number of waste packages required and total disposition costs.

\begin{tabular}{cccccc}
\hline $\begin{array}{c}\text { Design } \\
\text { Concept }\end{array}$ & $\begin{array}{c}\text { Number of } \\
\text { Canisters }\end{array}$ & $\begin{array}{c}\text { Number of } \\
\text { Canisters per } \\
\text { Waste Package }\end{array}$ & $\begin{array}{c}\text { Number of } \\
\text { Waste } \\
\text { Packages }\end{array}$ & $\begin{array}{c}\text { Cost per } \\
\text { Canister } \\
(\$ K)\end{array}$ & $\begin{array}{c}\text { Total Handling and } \\
\text { Disposition Cost } \\
(\$ K)\end{array}$ \\
\hline Concept A & 6,655 & 5 & 1,331 & $\$ 690.6$ & $\$ 4,595,877$ \\
Concept B & 4,071 & 5 & 815 & $\$ 1,036.9$ & $\$ 4,221,232$ \\
Concept C & 534 & 1 & 534 & $\$ 6,042.7$ & $\$ 3,226,782$ \\
\hline
\end{tabular}

\subsection{Cask Purchase}

To calculate the number of casks to purchase, it was first assumed that there will be five casks per consignment and that there will be a 3-week roundtrip time for each consignment. One of the driving factors for this element is the additional requirement to complete all of the consignments in no more than 12 years. (Note: This section is an OCRWM activity and cost only.)

The cask purchase price of $\$ 6,611 \mathrm{~K}$ each (Bradford and Gladson 1999, p. 9 of the attached cost estimate) in 1999 was escalated at 3\% per year for a cost per cask of \$7,894K in 2005.

\subsubsection{Concept A Cask Purchase}

With a maximum of five casks per consignment and a 3-week turnaround time for each consignment, it would take 16 years to make the required 267 consignments for Concept A canisters. Since this would not meet the requirement for completing the consignments in no more than 12 years, a second set of five casks would have to be purchased to make potentially concurrent consignments; this would reduce the total time required to ship, which would be approximately 8 years.

The total cask purchase price, therefore, would be $\$ 78,940 \mathrm{~K}$ for Concept A.

Concurrent shipment of two sets of casks in the 3-week turnaround time would essentially require a 1-1/2-week period (10.5 days) to complete each shipment. Given the 5-day time allowed in a 3-week schedule to load or unload casks at each end of the shipment, this would necessitate nearly continuous operation at both ends.

\subsubsection{Concept B Cask Purchase}

With a maximum of five casks per consignment and a 3-week turnaround time for each consignment, it would take about 9.4 years to make the required 163 consignments for Concept B canisters. Since this would meet the requirement for completing the consignments in no more than 12 years, only one set of five casks for the consignment would have to be purchased. 
The total cask purchase price for 5 casks would be $\$ 39,470 \mathrm{~K}$ for Concept B.

\subsubsection{Concept C Cask Purchase}

With a maximum of five casks per consignment and a 3-week turnaround time for each consignment, it would take about 6.2 years to make the required 108 consignments for Concept $\mathrm{C}$ canisters. Since this would meet the requirement for completing the consignments in no more than 12 years, only one set of five casks for the consignment would have to be purchased.

The total cask purchase price for 5 casks would be $\$ 39,470 \mathrm{~K}$ for Concept C.

\subsubsection{Summary of Cask Purchases}

Table 12 summarizes the cask purchase costs for the three design concepts with five casks per consignment.

Table 12. Number and cost of casks to purchase.

\begin{tabular}{ccccccc}
\hline Design & $\begin{array}{c}\text { Number of } \\
\text { Concept }\end{array}$ & $\begin{array}{c}\text { Number of } \\
\text { Casks per } \\
\text { Consignments }\end{array}$ & $\begin{array}{c}\text { Concurrent } \\
\text { Consignments } \\
\text { to Complete in } \\
<12 \text { years }\end{array}$ & $\begin{array}{c}\text { Number of } \\
\text { Casks to } \\
\text { Purchase }\end{array}$ & $\begin{array}{c}\text { C per } \\
\text { Cask } \\
(\$ K)\end{array}$ & $\begin{array}{c}\text { Total Cost } \\
(\$ K)\end{array}$ \\
\hline Concept A & 267 & 5 & 2 & 10 & $\$ 7,894$ & $\$ 78,940$ \\
Concept B & 163 & 5 & 1 & 5 & $\$ 7,894$ & $\$ 39,470$ \\
Concept C & 108 & 5 & 1 & 5 & $\$ 7,894$ & $\$ 39,470$ \\
\hline
\end{tabular}

\section{COST COMPARISON}

This section contains tables that summarize and compare the costs developed in Section 3, "Cost Elements Analyzed," for each canister design.

\subsection{Canister Purchase, Filling, and Sealing}

Given a total calcined waste volume of $155,800 \mathrm{ft}^{3}$ to be placed in canisters, Table 13 summarizes the number of canisters needed and their individual and total costs, including filling and sealing at the INTEC.

Table 13. Canister purchase data.

\begin{tabular}{ccccccc}
\hline $\begin{array}{c}\text { Design } \\
\text { Concept }\end{array}$ & $\begin{array}{c}\text { Canister } \\
\text { Volume } \\
\left(\mathrm{ft}^{3}\right)\end{array}$ & $\begin{array}{c}\text { Volume } \\
\text { \% Full }\end{array}$ & $\begin{array}{c}\text { Calcine } \\
\text { Volume } \\
\left(\mathrm{ft}^{3}\right)\end{array}$ & $\begin{array}{c}\text { Number of } \\
\text { Canisters } \\
\text { Needed }\end{array}$ & $\begin{array}{c}\text { Cost per } \\
\text { Canister } \\
(\$ \mathrm{~K})\end{array}$ & $\begin{array}{c}\text { Total Canister } \\
\text { Purchase Cost } \\
(\$ \mathrm{~K})\end{array}$ \\
\hline Concept A & 23.9 & 98 & 23.4 & 6,655 & $\$ 34.7$ & $\$ 230,929$ \\
Concept B & 39.1 & 98 & 38.3 & 4,071 & $\$ 47.9$ & $\$ 194,797$ \\
Concept C & 317.7 & 92 & 292.3 & 534 & $\$ 296.2$ & $\$ 163,505$ \\
\hline
\end{tabular}




\subsection{Shipping-Cask Preparation and Consignment Costs}

Table 14 summarizes the costs to prepare the appropriate number of shipping casks for each design concept for shipment from the INTEC to the MGR and the costs for consignments.

Table 14. Costs for preparing shipping casks and consignments.

\begin{tabular}{cccccc}
\hline Design & $\begin{array}{c}\text { Number of } \\
\text { Concept }\end{array}$ & $\begin{array}{c}\text { Number of } \\
\text { Casks per } \\
\text { Consignment }\end{array}$ & $\begin{array}{c}\text { Number of } \\
\text { Consignments }\end{array}$ & $\begin{array}{c}\text { Cost per } \\
\text { Consignment } \\
(\$ K)\end{array}$ & $\begin{array}{c}\text { Total } \\
\text { Consignment } \\
\text { Costs } \\
(\$ K)\end{array}$ \\
\hline Concept A & 1,331 & 5 & 267 & $\$ 265.0$ & $\$ 70,755$ \\
Concept B & 815 & 5 & 163 & $\$ 265.0$ & $\$ 43,195$ \\
Concept C & 534 & 5 & 108 & $\$ 245.0$ & $\$ 26,460$ \\
\hline
\end{tabular}

\subsection{Canister Handling and Final Disposition at the Monitored Geologic Repository}

The summary presented in Table 15 summarizes the costs to handle and fill the waste packages at the MGR surface facilities and to dispose of the waste packages in the subsurface facilities.

Table 15. Costs for waste package preparation and final disposition at the monitored geologic repository.

\begin{tabular}{cccccc}
\hline $\begin{array}{c}\text { Design } \\
\text { Concept }\end{array}$ & $\begin{array}{c}\text { Number of } \\
\text { Canisters }\end{array}$ & $\begin{array}{c}\text { Number of } \\
\text { Canisters per } \\
\text { Waste Package }\end{array}$ & $\begin{array}{c}\text { Number } \\
\text { Waste } \\
\text { Packages }\end{array}$ & $\begin{array}{c}\text { Cost per } \\
\text { Canister } \\
(\$ K)\end{array}$ & $\begin{array}{c}\text { Total Handling and } \\
\text { Disposition Cost } \\
(\$ K)\end{array}$ \\
\hline Concept A & 6,655 & 5 & 1,331 & $\$ 690.6$ & $\$ 4,595,877$ \\
Concept B & 4,071 & 5 & 815 & $\$ 1,036.9$ & $\$ 4,221,232$ \\
Concept C & 534 & 1 & 534 & $\$ 6,042.7$ & $\$ 3,226,782$ \\
\hline
\end{tabular}

\subsection{Cask Purchase}

Table 16 summarizes the cask purchase costs for the three design concepts and a maximum of five casks per consignment.

Table 16. Number and cost of casks to purchase.

\begin{tabular}{ccccccc}
\hline Design & $\begin{array}{c}\text { Number of } \\
\text { Number of } \\
\text { Concept }\end{array}$ & $\begin{array}{c}\text { Concurrent } \\
\text { Consignments } \\
\text { Consignments } \\
\text { to Complete } \\
\text { Consignt }\end{array}$ & $\begin{array}{c}\text { Number of } \\
\text { Casks to } \\
\text { in }\end{array}$ & $\begin{array}{c}\text { \$ per Cask } \\
(\$ K)\end{array}$ & $\begin{array}{c}\text { Total Cost } \\
(\$ K)\end{array}$ \\
\hline Concept A & 267 & 5 & 2 & 10 & $\$ 7,894$ & $\$ 78,940$ \\
Concept B & 163 & 5 & 1 & 5 & $\$ 7,894$ & $\$ 39,470$ \\
Concept C & 108 & 5 & 1 & 5 & $\$ 7,894$ & $\$ 39,470$ \\
\hline
\end{tabular}




\subsection{Summary of Costs}

All of the cost elements discussed above in Sections 3.1 through 3.4 and quantified in Sections 4.1 through 4.4 are summarized in Table 17.

Table 17. Summary of costs.

\begin{tabular}{|c|c|c|c|}
\hline Cost Element & $\begin{array}{c}\text { Concept A } \\
(\$ K)\end{array}$ & $\begin{array}{c}\text { Concept B } \\
(\$ K)\end{array}$ & $\begin{array}{c}\text { Concept C } \\
(\$ \mathrm{~K})\end{array}$ \\
\hline Canister purchase, filling, and sealing at the INTEC & $\$ 230,929$ & $\$ 194,797$ & $\$ 163,505$ \\
\hline Shipping cask preparation and consignment costs & $\$ 70,755$ & $\$ 43,195$ & $\$ 26,460$ \\
\hline Canister handling and final disposition at the MGR & $\$ 4,595,877$ & $\$ 4,221,232$ & $\$ 3,226,782$ \\
\hline Cask purchase & $\$ 78,940$ & $\$ 39,470$ & $\$ 39,470$ \\
\hline Grand Total (\$K) & $\$ 4,976,501$ & $\$ 4,498,694$ & $\$ 3,456,217$ \\
\hline Savings Relative to Concept A (\$K) & $\$ 0$ & $\$ 477,807$ & $\$ 1,520,284$ \\
\hline
\end{tabular}

\subsection{Opportunity Costs}

Although they cannot be quantified for this analysis, there are a few opportunity costs that should be mentioned:

- As pointed out in Section 3.4, "Cask Purchase," given the same number of casks, there is a wide variation in the amount of time required to complete the shipping campaigns for the three design concepts. The least amount of time- 6.2 years for Concept $\mathrm{C}$ - could allow for much more flexibility in scheduling and could reduce the number of casks required if consignments were actually completed over the 12-year schedule. The same can be said to a lesser extent for Concept B at 9.4 years. Concept A would be much less flexible in this regard (7.7 years with double the frequency of shipment). Additionally, a shorter shipping campaign will allow for a cost reduction in INTEC support functions and allow for earlier site closure.

- $\quad$ With regard to Section 4.3, "Canister Handling and Final Disposition at the Monitored Geologic Repository," it is believed that it will take significantly less time to emplace 534 canisters (Concept C) into waste packages versus the emplacement of the 6,655 and 4,071 canisters associated with Concepts $\mathrm{A}$ and $\mathrm{B}$, respectively. Less time also reduces worker exposure while increasing throughput in the packaging facilities.

- $\quad$ As previously discussed in Section 3.3, "Canister Handling and Final Disposition at Yucca Mountain," an important cost savings opportunity would be the reduction in the amount of subsurface tunnel space (in linear feet) needed for Concept $\mathrm{C}$ in particular. Without accounting for additional spacing between fewer waste packages (534 for Concept $\mathrm{C}$ versus 815 for Concept $\mathrm{B}$ and 1,331 for Concept A) and the thickness of the waste package tops and bottoms (factors that would only amplify the cost difference among the three design concepts), the linear feet required for the disposition of Concept $\mathrm{C}$ canisters would result in about 9,345 linear $\mathrm{ft}$ of space. Concept $\mathrm{A}$ would require about 13,310 linear $\mathrm{ft}$ and Concept $\mathrm{B}$ would require about 12,225 linear $\mathrm{ft}$. This adds up to a savings in linear feet of tunnel space for Concept $\mathrm{C}$ of a maximum of 3,965 ft - roughly a $0.75 \mathrm{mi}$ of tunnel space that could be used for other waste disposal. This opportunity cost is graphically depicted in Figure 4. 
- $\quad$ Finally, the number of transportation casks required for Concept $\mathrm{C}$, which uses a Navy cask, could be reduced by leasing casks from or sharing costs with the Navy.

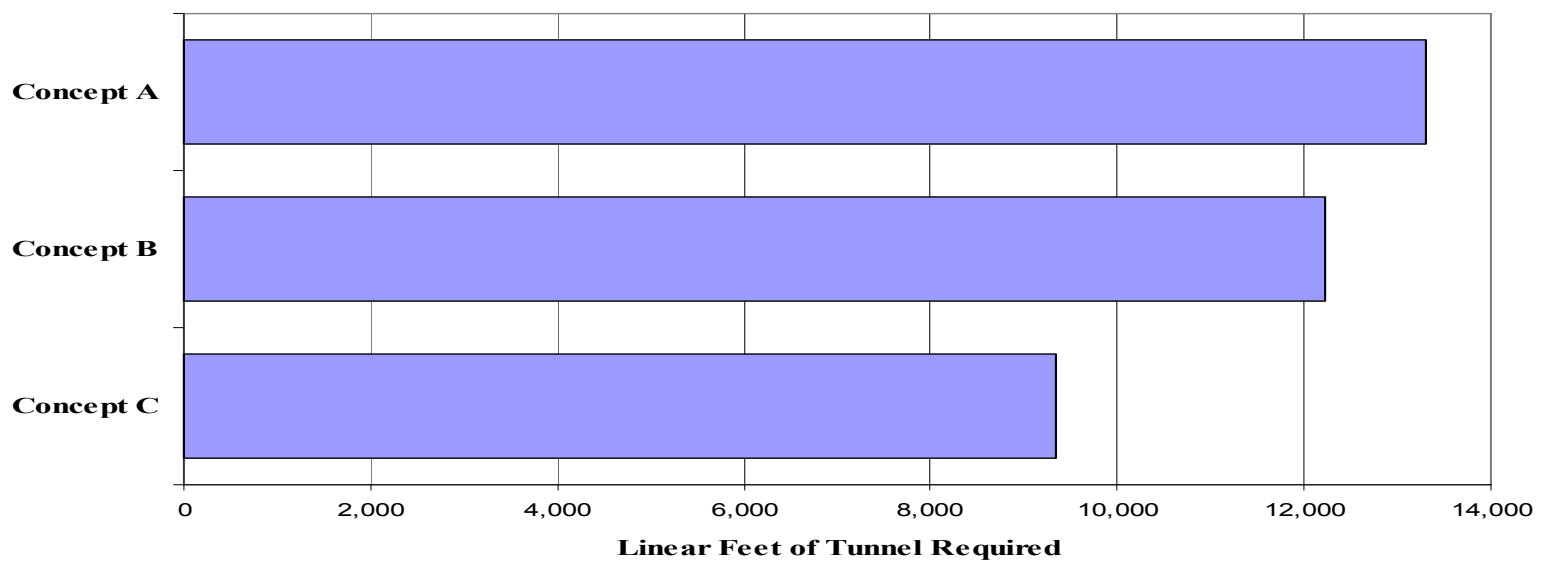

Figure 4. Linear feet of tunnel space required (without spacing) for three canister designs.

\section{SUMMARY}

The purpose of this report is to identify, quantify, and compare life-cycle costs that are unique to three proposed canister designs for the shipment and disposition of high-level calcined waste from the INTEC to the proposed national MGR at Yucca Mountain, Nevada. Unique life-cycle costs include elements such as canister purchase and filling at INTEC, cask preparation and roundtrip consignment costs, final disposition in the MGR (including canister off-loading and placement in the final waste disposal package for disposition), and cask purchase. The three canister designs selected for this report are Concept A $(2 \times 10 \mathrm{ft})$, Concept $\mathrm{B}(2 \times 15 \mathrm{ft})$, and Concept $\mathrm{C}(5.5 \times 17.5 \mathrm{ft})$ canisters.

This report concludes that the life-cycle costs for Concept $\mathrm{C}$ are approximately $\$ 1.5 \mathrm{~B}$ lower than Concept A and \$1.0B lower than Concept B. In fact, Concept C (also called the "Super Canister") had the lowest life-cycle cost in every element evaluated. The report also identifies other unquantifiable "opportunity" costs such as (1) the amount of time required to complete the shipping campaigns for the three design concepts, (2) impact on canister handling, worker exposure, and throughput at the MGR, and (3) the amount of linear feet required for the disposition of the canisters, which concludes that Concept $\mathrm{C}$ will save $0.75 \mathrm{mi}$ of tunnel space over the other concepts.

\subsection{Comparison of Direct Packaging to Direct Vitrification}

An additional comparison can be made from information derived in this analysis. Direct vitrification of INL HLW calcine would result in 12,000 10-ft canisters (see the Idaho High-Level Waste and Facilities Disposition Final Environmental Impact Statement [DOE 2002], Table 3-2, p. 3-8, "Early Vitrification Option"). Using the equation shown in Figure 3-1 of this report, the INL share of the MGR cost for 12,000 canisters would be \$7.1B in FY 2005 dollars escalated at 3\% per year. This is $\$ 3.9 \mathrm{~B}$ more than the $\$ 3.2 \mathrm{~B}$ repository cost for 534 Concept $\mathrm{C}$ canisters for the direct packaging alternative. Direct vitrification is $120 \%$ more expensive than Concept $\mathrm{C}$ and $50 \%$ more expensive than Concept $\mathrm{A}$ in repository costs. 
Table 18 compares the repository cost for disposal of 12,000 10-ft canisters of directly vitrified glass to the directly packaged canister alternatives addressed in this report.

Table 18. Comparison of direct vitrification vs. direct-packaged costs for final disposition at the monitored geologic repository.

\begin{tabular}{|l|c|c|c|c|}
\hline \multicolumn{1}{|c|}{ Design Concept } & $\begin{array}{c}\text { Number of } \\
\text { Canisters }\end{array}$ & $\begin{array}{c}\text { Total Repository } \\
\text { Handling and } \\
\text { Disposition Cost } \\
(\$ \mathrm{~K})\end{array}$ & $\begin{array}{c}\text { Additional Cost } \\
\text { Relative to Concept C, } \\
\text { the lease costly case } \\
(\$ \mathrm{~K})\end{array}$ & $\begin{array}{c}\text { Savings Relative to } \\
\text { Direct Vitrification, } \\
\text { the Most Costly Case } \\
(\$ \mathrm{~K})\end{array}$ \\
\hline $\begin{array}{l}\text { Concept A } \\
\text { Direct packaged } \\
2 \times 10 \text {-ft-L canister }\end{array}$ & 6,655 & $\$ 4,595,877$ & $\$ 1,369,095$ & $\$ 2,516,783$ \\
\hline $\begin{array}{l}\text { Concept B } \\
\text { Direct packaged } \\
2 \times 15 \text {-ft-L canister }\end{array}$ & 4,071 & $\$ 4,221,232$ & $\$ 994,450$ & $\$ 2,891,428$ \\
\hline $\begin{array}{l}\text { Concept C } \\
\text { Direct packages } \\
5.5 \times 17.5 \text {-ft-L canister }\end{array}$ & 534 & $\$ 3,226,782$ & $\$ 0$ & $\$ 3,885,878$ \\
\hline $\begin{array}{l}\text { Direct vitrification } \\
2 \times 10 \mathrm{ft}-\mathrm{L}-\text { canister }\end{array}$ & 12,000 & $\$ 7,112,660$ & $\$ 3,885,878$ & \\
\hline
\end{tabular}

Visually the additional length of tunnel required for direct vitrification can be seen in Figure 5, a modification of Figure 4. Direct vitrification would require 24,000 linear $\mathrm{ft}$ of tunnel. This is $14,655 \mathrm{ft}$ (approximately $2.8 \mathrm{mi}$ ) or $157 \%$ more than that for Concept C.

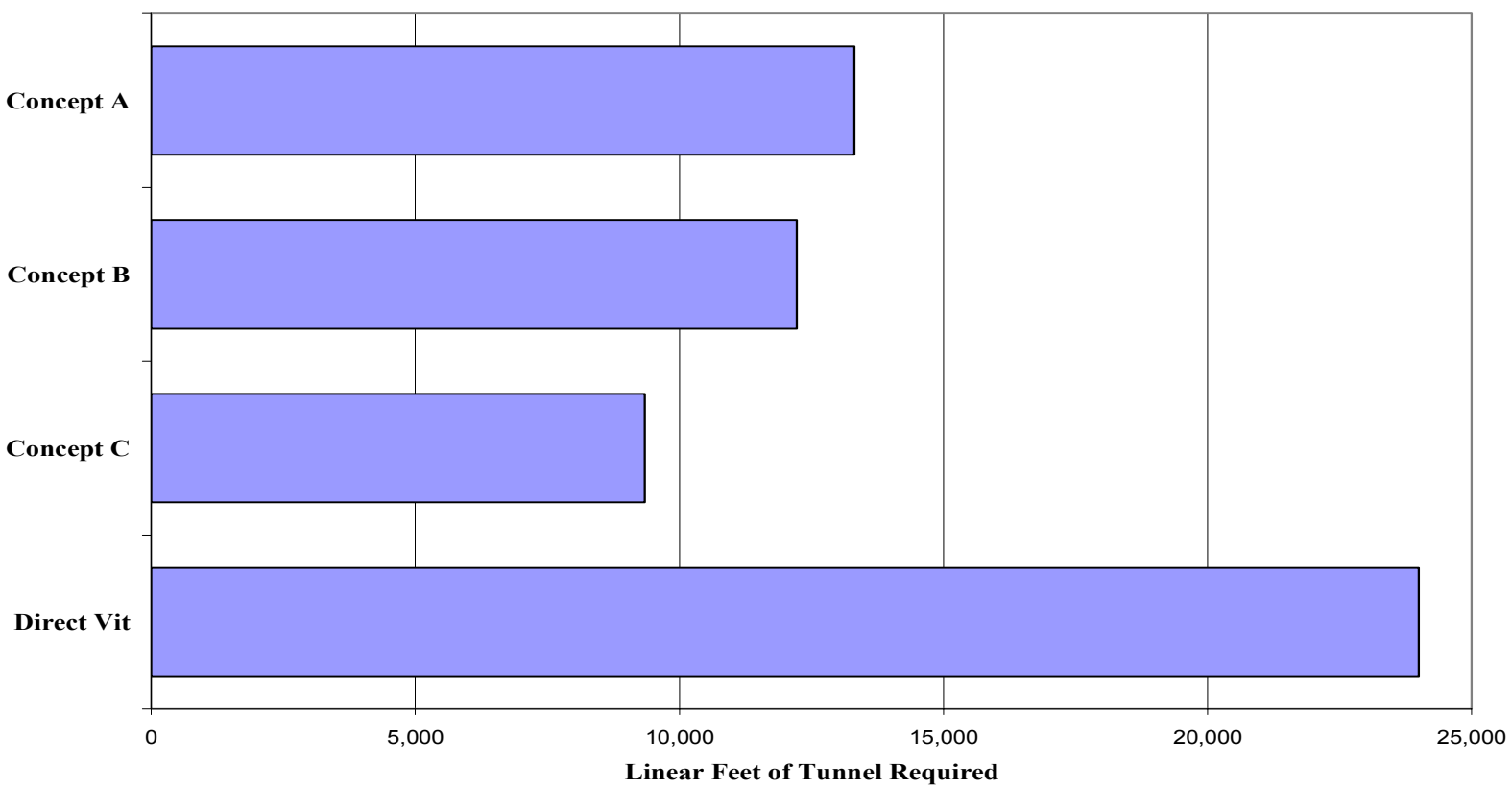

Figure 5 (modified Figure 4). Linear feet of Yucca Mountain tunnel space required (without spacing) for three canister designs compared to direct vitrification in 10-ft canisters. 


\section{REFERENCES}

10 CFR 71, 2004, "Packaging and Transportation of Radioactive Material," Code of Federal Regulations, Office of the Federal Register, October 2004.

Bradford, S. M. memorandum to P. D. Wheatley, June 8, 1998, "DOE Standardized Spent Nuclear Fuel Canisters," SMB-21-98.

Bradford, S. M. memorandum to S. C. Gladson, October 7, 1999, "National Spent Nuclear Fuel/National Spent Nuclear Fuel Project/Transportation," SMB-49-99.

DOE, 1999, Preliminary Design Specification for Department of Energy Standardized Spent Nuclear Fuel Canisters, Volume 1-Design Specification, DOE/SNF/REP-011, Rev. 3, U.S. Department of Energy, August 1999.

DOE, 2001, Total System Life Cycle Cost Study of the Civilian Radioactive Waste Management Program, DOE/RW-0533, U.S. Department of Energy, Office of Civilian Radioactive Waste Management, May 2001.

DOE, 2002, Idaho High-Level Waste and Facilities Disposition Final Environmental Impact Statement, DOE/IS-0287, U.S. Department of Energy, September 2002.

EDF-3673, 2003, "Pneumatic Retrieval of Calcined High-Level Waste,” Rev. 0, Idaho National Engineering and Environmental Laboratory, July 2003.

EDF-4096, 2003, "FY2003 Conceptual Design Effort for the High Level Waste Disposal Canister," Rev. 0, Idaho National Engineering and Environmental Laboratory, August 2003.

EDF-4504, 2005, “A Summary of Properties Used to Evaluate INL Calcine Disposal in the Yucca Mountain Repository,” Rev. 3, Idaho National Laboratory, Idaho Completion Project, April 2005.

Keister, M., 2002, “Cross Country Transport,” Work Package Plan WBS: C.2.04.01.01.01.02.

Lopez, P., 2002, Total Life Cycle and Defense Share Cost Study for INEEL Calcine Treatment Alternatives, TDR-CRW-SW-000015, Rev. 01, Bechtel SAIC Company, LLC, January 2002.

Stacy, S. M., 2000, Proving the Principle: A History of the Idaho National Engineering and Environmental Laboratory 1949-1999, DOE/ID-10799, Rev. 0, U.S. Department of Energy Idaho Operations Office, pp. 169-172.

Staiger, M. D. and M. C. Swenson, 2005, Calcined Waste Storage at the Idaho Nuclear Technology and Engineering Center, INEEL/EXT-98-00455, Rev. 2, Idaho National Engineering and Environmental Laboratory, January 2005. 